\title{
Когда был опубликован фельетон Ф. М. Достоевского «Тритон»? \\ (Из цензурной истории еженедельника «Гражданин» в 1878 г.) $)^{*}$
}

\begin{abstract}
Аннотация. В статье уточняется цензурная история № 23-25 «Гражданина» 1878 г., содержащего фельетон Ф. М. Достоевского «Тритон» («Из дачных прогулок Кузьмы Пруткова и его друга») - последнюю известную публикацию писателя в данном журнале в период его издания в С.-Петербурге. На основании ряда документов, обнаруженных в архивах С.-Петербургского цензурного комитета и Главного управления по делам печати МВД, устанавливается, что весь тираж № 23-25 «Гражданина», датированного 10 октября 1878 г., был арестован цензурой и назначен к уничтожению; причиной карательной меры стали материалы номера, выражавшие сочувствие опальному публицисту и общественному деятелю И. С. Аксакову. Издателю-редактору «Гражданина» В. Ф. Пуцыковичу, подавшему 11 октября 1878 г. прошение на имя министра внутренних дел А. Е. Тимашева, удалось отстоять арестованный номер журнала, согласившись на ряд изменений в его содержании и перепечатку его отдельных страниц. Исправленный № 23-25 «Гражданина» с фельетоном «Тритон» увидел свет не ранее 16 октября 1878 г. Выявленные в архивах цензурных инстанций документы, иллюстрирующие историю выхода в свет № 23-25 «Гражданина», публикуются впервые; публикация документов сопровождается реальным комментарием.
\end{abstract}

Ключевые слова: «Гражданин», В. Ф. Пуцыкович, И. С. Аксаков, фельетон «Тритон», С.-Петербургский цензурный комитет

B трехтомной «Летописи жизни и творчества Ф. М. Достоевского» (СПб., 1993-1995) выходу в свет фельетона «Из дачных прогулок Кузьмы Пруткова и его друга» («Тритон») посвящена всего одна лаконичная фраза в разделе «1878 г.»: «Октября 10. В Гр<ажданине> (№ 23-25) опубликован фельетон Д<остоевского> “Из дачных прогулок Кузьмы Пруткова и его друга"» [Летопись, III: 289]. Дата «1878. 10 Октября» обозначена и на первой странице самого № 23-25 «Гражданина» за 1878 г., и, казалось бы, оспаривать ее достоверность у исследователей журнала нет оснований. Долгая и весьма хлопотная для издателя-редактора «Гражданина» В. Ф. Пуцыковича история прохождения № 23-25 через цензуру (лишь начавщаяся 10 октября 1878 г.) еще не была известна на момент подготовки к изданию «Летописи жизни и творчества Ф. М. Достоевского». Лишь спустя одиннадцать лет после выхода 3-го тома «Летописи...» первое документированное исследование цензурной истории «Гражданина» в 1878 г. будет представлено И. А. Прониной в статье «Последний год “Гражданина”: К истории отношений правительственной цензуры и консервативной печати». Работа И. А. Прониной подготовлена по материалам хранящегося в РГИА дела Главного управления 
по делам печати МВД по изданию «Гражданина». Из этого исследования мы узнаём (по упоминанию в приводимой в пересказе служебной записке цензора Н. В. Варадинова министру внутренних дел) о некоем наказании, грозившем «Гражданину» в октябре 1878 г., и об аресте по инициативе председателя С.-Петербургского цензурного комитета А. Г. Петрова (очевидно, также в октябре того же года) очередного номера газеты-журнала за статью В. П. Мещерского, выражавшую поддержку недавно высланному из Москвы за «политическую неблагонадежность» И. С. Аксакову [Пронина: 24, 30]. Из отношения А. Г. Петрова на имя начальника Главного управления по делам печати исследователем приводится следующая цитата: «Имея в виду, что эта прославляемая <«Гражданином»> деятельность Аксакова была поводом последовавшего распоряжения о выезде его из Москвы, и признавая такое восхваление крайне неуместным, я принял надлежащие меры к задержанию номера» [Пронина: 24]. О каком номере «Гражданина» идет речь, И. А. Пронина не уточняет. Не позволяет это понять и архивная ссылка при дословной выдержке из отношения А. Г. Петрова, очевидно ошибочная, в которой цитируемый документ именуется «отношением и<справляющего > д<олжность> начальника Главного управления по делам печати на имя министра внутренних дел, 1878, 20 сент<ября> (выделено мной. - A. О.)» и указывается шифр: РГИА. Ф. 776.5.1871.95. Ч. 1. Л. 280 [Пронина: 30]. Известно, что в сентябре 1878 г. «Гражданин» вообще не выходил в свет, поскольку 4 июля издание было приостановлено на три месяца за напечатание «разгромной» речи того же И. С. Аксакова против Берлинского международного конгресса по балканскому вопросу (см.: РГИА. Ф. 776.1.14. Л. 37-38). Сверка публикации И. А. Прониной с материалом использованных автором архивных источников выявляет ряд допущенных в статье ошибок и неточностей. Так, цитируемое отношение А. Г. Петрова в Главное управление по делам печати в оригинале датировано 10 октября 1878 г. и составляет в деле «Гражданина» л. 285-285 об. (а не л. 280). Этот документ (судя как по его содержанию, так и по порядку расположения официальных бумаг в деле «Гражданина») предшествует служебной записке Н. В. Варадинова министру внутренних дел, помеченной той же датой, тогда как И. А. Прониной последовательность составления деловых бумаг представлена иначе (ср.: [Пронина: 24]). Н. В. Варадинов, именуемый в статье «секретарем Главного управления по делам печати» [Пронина: 24], в действительности занимал должность члена Сoвета Главного управления по делам печати ${ }^{1}$, а автором «хвалебной» статьи «Гражданина» об И. С. Аксакове был (судя по подписи под статьей, а также по стилистическим особенностям текста) не В. П. Мещерский, а редактор журнала В. Ф. Пуцыкович (см.: РГИА. Ф. 777.2.1871.74. Л. 169-170).

Материалы дела Главного управления по делам печати по изданию журнала «Гражданин» не оставляют сомнения в том, что 10 октября 1878 г. был задержан тираж отпечатанного в этот день № 23-25 «Гражданина». Из служебной записки Н. В. Варадинова министру внутренних дел А. Е. Тимашеву 
и резолюции министра на документе явствует, что весь тираж этого номера планировалось уничтожить, на что предполагалось получить санкцию Александра II (см. ниже публикацию служебной записки). Таким образом, последний опыт выступления Ф. М. Достоевского в печати в качестве фельетониста и юмориста - фельетон «Из дачных прогулок Кузьмы Пруткова и его друга» - мог вовсе не выйти в свет (по крайней мере, при жизни автора).

Немногочисленные связанные с № 23-25 «Гражданина» материалы соответствующего дела Главного управления по делам печати не дают ответов на вопросы о том, как арестованный номер журнала смог избежать уничтожения и куда из него исчезли тексты, вызвавшие нарекания цензуры (кроме статьи В. Ф. Пуцыковича «Воспоминания об И. С. Аксакове», таковыми были стихотворение И. С. Аксакова «Варварино» и открывавшее журнальный выпуск заявление «От редакции»). Отсутствие соответствующих материалов в деле по «Гражданину» Главного управления по делам печати указывает на целесообразность их поиска в других архивных делах цензурного ведомства. Действительно, в журнале заседаний Совета Главного управления по делам печати за 1878 г. обнаруживается протокол посвященного № 23-25 «Гражданина» заседания Совета 10 октября 1878 г. (см.: РГИА. Ф. 776.2.18. Л. 412-414). Данный документ, однако, мало что прибавляет к уже известным нам фактам.

Основной массив документов, иллюстрирующих цензурную историю злосчастного № 23-25 «Гражданина», был выявлен нами в архиве подчиненной Главному управлению инстанции - С.-Петербургского цензурного комитета. В деле комитета по изданию журнала «Гражданин» (РГИА. Ф. 777.2.1871.74) сохранилось 14 деловых бумаг ${ }^{2}$, отражающих практически все стадии «эпопеи» с арестом и последующим освобождением тиража № 23-25 журнала. Последние из этих документов датированы 16 октября 1878 г.: лишь в этот день освобожденный из-под ареста номер было наконец разрешено разослать подписчикам. Ключевую роль в снятии ареста с номера сыграло прошение В. Ф. Пуцыковича 11 октября 1878 г. на имя министра внутренних дел А. Е. Тимашева. Обращаясь к министру, издатель-редактор «Гражданина» настаивал на выпуске в свет своего журнала в том виде, в котором он был изначально отпечатан 10 октября. А. Е. Тимашев, не согласившись с В. Ф. Пуцыковичем, разрешил выпуск под условием изъятия из него забракованных цензурой текстов, с обязательным представлением «исправленного» № 23-25 на предварительный цензурный просмотр. Пуцыкович был вынужден выполнить требование министра. Все выявленные в архивах цензурного ведомства документы, касающиеся № 23-25 «Гражданина» 1878 г., публикуются нами полностью в составе настоящей работы.

Содержание запрещенных материалов № 23-25 «Гражданина» 1878 г. (они также сохранились в архивах Главного управления по делам печати и С.Петербургского цензурного комитета) определенно свидетельствует о настрое издателя-редактора журнала на конфронтацию, его желании «дразнить» 
цензуру заведомо непозволительными выходками. Такое желание, отметим, неоднократно проявлялось В. Ф. Пуцыковичем - редактором «Гражданина» - и прежде, и после истории с № 23-25 журнала за 1878 г. Эти неосторожные и бестактные выходки В. Ф. Пуцыковича как издателя-редактора нередко вызывали неодобрительную реакцию Достоевского. Сам Пуцыкович в 1903 г. в одной из мемуарных заметок о Достоевском вспоминал о том, как еще в июне 1878 г. писатель пытался его отговорить от публикации в «Гражданине» знаменитой речи И. С. Аксакова 22 июня 1878 г. против Берлинского международного конгресса (подробнее о ней см. ниже комментарий к отношению С.-Петербургского цензурного комитета в Главное управление по делам печати от 10 октября 1878 г.). «Ой смотрите, чтобы васъ за это не выслали», - предупреждал Достоевский самого И. С. Аксакова, присутствовавшего при этом разговоре. «И когда съ нашей стороны, вспоминал В. Ф. Пуцыкович, - высказывались сомнънія, такъ какъ мы, обсудивъ всъ шансы, были увърены, что все дъло кончится предостереженіемъ “Гражданину”, онъ со свойственною ему живостью почти вскрикнулъ: “Такъ я же вамъ предсказываю, что васъ вышлютъ за эту ръчь!”». Предсказание Достоевского, как мы знаем, сбылось в точности.

Спустя год, когда В. Ф. Пуцыкович, выехав за границу, чтобы избежать долговой тюрьмы в России, возобновил издание «Гражданина» в Берлине, он вновь выступил в своем журнале с критикой «пораженческой» позиции русских дипломатов на Берлинском международном конгрессе 1878 г. При этом издатель «Гражданина» не удержался от личных оскорблений в адрес известных русских высокопоставленных чиновников. Такая бессмысленная бравада вызвала отповедь Достоевского в письме Пуцыковичу от 14 (26) августа 1879 г. В нем писатель указывал корреспонденту на возможность убедительно доносить свою мысль до сознания читателей, обходя «подводные камни» цензуры и не делая хлестких заявлений, рассчитанных лишь на внешний эффект. «Многоуважаемый Виктор <ъ> Өеофиловичь, - писал Достоевский, - Гражданинъ я получиль <...> но удивили Вы меня очень: Неужели Вы думаете что наша Цензура пропустить его въ Россію? Если же не пропустить - зачпмь было и издавать? <...> И какъ это Вы ухитрились надплать столько промаховъ? Я представить не могу чтобъ цензура могла пропустить тичныя оскорбленія извтстныхъ сановниковъ и глумленіе надь ними. <...> Посмотрите как<ъ> у насъ, подъ такой цензурой, газеты ухитряются говорить объ этомъ: Въ Москов<скихъ > Видом< остяхъ > я о Конгрессп читал посильнте Вашихъ обличенія въ 10 разъ <...> Как<ъ> это столько литть издавая журналь не выработать въ себю чувства мпрры. <... Виьдь эти глумленія ничего не прибавляють къ смыслу.

\section{Тоже бы ты слово \\ Да не такъ бы молвиль}

говорить постовииа. Досаднтье всего то что № весьма не дуренъ и дпйствительно привлекв бы подписчиковъ. $<. .>$ Не сердитесь: Это не наставленія, это 
невольная досада, за то что самъ же человпк<ъ> свое же дюло губитъ» (РГАЛИ. Ф. 212.1.45. Л. 4-5; ср.: Д30, 30 , 112-113).

Урок, данный Достоевским в цитируемом письме, был усвоен Пуцыковичем еще очень нескоро. Для этого издателю-редактору «Гражданина» потребовались годы полуголодной жизни в Берлине, окончательный финансовый крах его газеты-журнала в 1880 г., вынудивший публициста к поиску случайных заработков в качестве берлинского корреспондента разных русских изданий, и, наконец, унизительный для Пуцыковича опыт сотрудничества с газетой «Новое Время», не близкой журналисту по направлению и прежде ему совершенно ненавистной (см.: [Отливанчик, 2010: 205-206]). Гораздо позднее, в 1896 г., вступив в переговоры с издателем-редактором журнала «Русское Обозрение» А. А. Александровым и предлагая себя на роль ведущего рубрики «Иностранное обозрение» в этом издании, В. Ф. Пуцыкович уже в достаточно критическом тоне будет вспоминать свои прежние хлесткие бравады на страницах «Гражданина»: публицист специально оговорит в письме редактору, что не собирается в статьях для «Русского Обозрения» "ругать дипломатовъ, какъ было во время оно (1876-79 г<г.>)» (РГАЛИ. Ф. 2.1.717. Л. 13 об.-14).

Документы из архивов С.-Петербургского цензурного комитета и Главного управления по делам печати МВД публикуются по подлинникам в хронологическом порядке.

1.

Отношение С.-Петербургского цензурного комитета на имя С.-Петербургского градоначальника (черновик) 10 октября 1878 г.

МИНИСТЕРСТВО

ВНУТРЕННИХЪ ДЋЛЬ.

С.-ПЕТЕРБУРГСКІЙ ЦЕНЗУРНЫЙ КОМИТЕТЪ.

С.-ПЕТЕРБУРГ. «10» октября 1878 г. № 1283 .

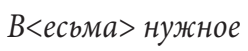

Господину ${ }^{4}<<.>$ Петербургскому Градоначальнику ${ }^{5}$.

Импю честь покорнпйше просить Ваше Превосходительство сдплать зависящее со стороны Вашей распоряженіе объ арестованіи экземпляровъ № 23/25 газеты «Гражданинъ» оть $10^{20}$ октября, ${ }^{8}$ отпечатанныхъ въ Типограбіи Траншеля (Стремянная, 12). ${ }^{9}$

Кв сему имюю честь присовокупить, что о задержаніи экземпляровъ сего номера, сданныхъ на почту, мною сообщено С. Петербургскому Почть Директору.

О посльдствіяхь настоящаго сообщенія моего импю честь покорнпйше просить Ваще Превосходительство почтить меня увпдомленіемь.

Предстьдатель

Секретарь <л. 172>

Источник текста: РГИА. Ф. 777.2.1871.74. Л. 172. 
Черновик выполнен рукой писца; имеются вставки рукой секретаря С.Петербургского цензурного комитета Н. И. Пантелеева.

\section{Комментарии:}

Господину C<.> Петербургскому Градоначальнику. - Должность С.-Петербургского градоначальника в период с мая 1878 г. по май 1880 г. занимал Александр Эльпидифорович Зуров (1837-1902), государственный и военный деятель.

...въ Типограбіи Траншеля... - Траншель (Tranzschel) Генрих-Фердинанд (Андрей Иванович; 1828-1887) - литограф, владелец типографии в С.-Петербурге, саксонский (с 1871 г. - германский) подданный. В типографии А. И. Траншеля в 1870-е гг. печатался журнал «Гражданин».

Предсnдатель - Председателем С.-Петербургского цензурного комитета в 1865-1887 гг. был Александр Григорьевич Петров (1803-1887), в 1870-1880-е гг. совмещавший эту должность с членством в Совете Главного управления по делам печати МВД.

Секретарь - Секретарем С.-Петербургского цензурного комитета в 1870-1898 гг. был Николай Иванович Пантелеев (1838-1915), служивший в цензурном ведомстве с 1866 г. (впоследствии, в 1898-1915 гг., член Совета Главного управления по делам печати МВД).

2.

Отношение С.-Петербургского цензурного комитета на имя старшего инспектора типографий и книжной торговли в С.-Петербурге (черновик) 10 октября 1878 г.

МИНИСТЕРСТВО

ВНУТРЕННИХЪ ДЪЛЪ.

С.-ПЕТЕРБУРГСКІЙ ЦЕНЗУРНЫЙ КОМИТЕТЪ.

\section{С.-ПЕТЕРБУРГ. «10» октября 1878 г. № 1284 .}

В<есьма $>$ нужное.

Господину Старшему Инспектору Типограбій въ $C<$.> Петербургп

Импю честь покорнпйше просить Ваше Превосходительство принять безотлагательно мпры кб задержанію экземпляровъ № 23'25 газеты «Гражданинб» оть 10 октября ${ }^{11}$, какъ находящихся въ типографіи Траншеля, гдь газета печатается, такъ и поступивщихъ уже въ розничную продажу.

Къ сему считаю необходимьмъ присовокупить, что мною, вмпьстп съ симб, сообщено о задержаніи экземпляровъ сего номера Господину Исправляющему должность C<.> Петербургскаго Градоначальника и $C<.>$ Петербургскому Почть Дирекmopy<.>

О посльдствіяхъ принятыхъ Вами къ задержанію мпрг покорнпйше прошу почтить меня увпдомленіемь<.>

Предспдатель

Секретарь Н. Пантелеев<в $>^{12}<$ л. 173>

Источник текста: РГИА. Ф. 777.2.1871.74. Л. 173.

Черновик выполнен рукой писца; подпись секретаря — автограф Н. И. Пантелеева. 


\section{Комментарии:}

Господину Старшему Инспектору Типографій въ С<.> Петербургп - Должность старшего инспектора типографий и т. п. заведений, а также книжной торговли в С.-Петербурге с декабря 1873 г. по август 1897 г. занимал Николай Васильевич Никитин (1827-1903). В архиве Главного управления по делам печати МВД сохранилась данная Ф. М. Достоевским Н. В. Никитину 13 марта 1874 г. расписка с обязательством напечатать в «Гражданине» распоряжение министра внутренних дел о первом цензурном предостережении изданию (см.: РГИА. Ф. 776.5.1871.95. Ч. 1. Л. 102; ср.: Д30, 29, 378). В деле С.-Петербургского цензурного комитета по изданию журнала «Гражданин» имеется ряд отношений комитета на имя старшего инспектора типографий и книжной торговли (в копиях) с ответными уведомлениями старшего инспектора (в подлинниках) и деловое письмо В. Ф. Пуцыковича Н. В. Никитину от 30 апреля 1878 г. (см.: РГИА. Ф. 777.2.1871.74. Л. 57-57 об., 65, 87-87 об., 91-92, 95-97 об., 135-136 об. и др.).

«русское обозрпніе» (сноска 11). - «Русское Обозрение» - еженедельная газета либерального направления, издававшаяся с июля 1876 г. по февраль 1878 г. Г. К. Градовским, первым редактором журнала «Гражданин». За полтора года издания газета «Русское Обозрение» получила 11 цензурных предостережений и после 5 февраля 1878 г. не выходила в свет (позднее была запрещена и формально распоряжением правительства). Ввиду частых конфискаций тиража «Русского Обозрения» в канцелярии С.-Петербургского цензурного комитета, очевидно, были заготовлены рукописные бланки соответствующих распоряжений на имя старшего инспектора типографий и книжной торговли, С.-Петербургского почтдиректора и др. должностных лиц (по мере необходимости в бланки вписывались подлежащие аресту номера газеты). Бланки, «не израсходованные» на момент закрытия «Русского Обозрения», позднее использовались как черновики распоряжений о конфискации номеров других изданий, в т. ч. «Гражданина» (см. следующий публикуемый документ).

3.

Отношение С.-Петербургского цензурного комитета на имя

С.-Петербургского почт-директора (черновик)

10 октября 1878 г.

МИНИСТЕРСТВО ВНУТРЕННИХЪ ДЂЛЪ.

\section{С.-ПЕТЕРБУРГСКІЙ ЦЕНЗУРНЫЙ КОМИТЕТЪ.}

\section{С.-ПЕТЕРБУРГ.} «10» октября 1878 r. № 1285
$\underline{B<е с ь м а>~ н у ж н о е . ~}$

Господину С. Петербургскому Почтъ Директору

Импю честь покорнпйше просить Ваме Превосходительство сдюлать распоряженіе о задержаніи экземпляровъ № 23/2513 газеть <«>Гражданинъ», отъ 10 сего октября, ${ }^{14}$ сданныхъ на почту для разсылки какъ городскимг, такъ и иногороднымг подписчикамъ, и о послюдствіяхъ распоряженій Вашихъ по сему почтить меня увпдомленіемъ. ${ }^{15}$ 
Источник текста: РГИА. Ф. 777.2.1871.74. Л. 174.

Черновик выполнен рукой писца.

\section{Комментарии:}

Господину С. Петербургскому Почтъ Директору - Должность С.-Петербургского почт-директора в 1868-1886 гг. занимал Владимир Федорович Шор (?-1886).

4.

\section{Отношение С.-Петербургского цензурного комитета на имя исправляющего должность начальника Главного управления по делам печати}

\section{0 октября 1878 г.}

МИНИСТЕРСТВО ${ }^{16}$ ВНУТРЕННИХъ ДъЛЬ.

С.-ПЕТЕРБУРГСКІЙ ЦЕНЗУРНЫЙ КОМИТЕТЬ.

\section{С.-ПЕТЕРБУРГ.} «10» Октября 1878 г. № 1282 .
Господину Исправляющему должность Начальника Главнаго Управленія по дтламг печати.

Въ представленномъ сегодня изг типографіи Траншеля 2325 номерг «Гражданина», оть 10 Октября, помпщено распоряженіе Г. Министра Внутреннихъ Дгль о пріостановкп журнала на три мпосяи, $a^{17}$.

Поводомъ къ этому распоряженію, какъ извпостно Вашему Превосходительству, послужила ргчь Аксакова, напечатанная вь приложеніи къ 23-24 номеру этого изданія.

Въ представленномг сегодня номерпо помпщено стихотвореніе Аксакова: «Варварино», въ началь котораго авторг заявляеть, что «вихрь злой бури снесъ его домъ и онъ теперь изгнанникъ». Далье выражается сладостное чувство успокоенія въ тихомб пристанищль, среди прекрасной деревенской природы, <л. 285> и надежда на окончательное преодоленіе Россіей враждебнаго ей міра; но счастливый часъ этого торжества не близокъ: ${ }^{18}$ потому что «злая мгла облегла вершины Руси»<.>

Далпе помпщена статья, подъ заглавіемъ: «Воспоминанія объ И. С. Аксаковпь», въ которой съ крайнимг сочувствіемъ описывается предъидущая журнальная дпятельность Аксакова и заслуги ${ }^{19}$ по предспдательству въ Славянскомъ Обществиь.

Импя вг виду, что эта прославляемая дпятельность Аксакова была поводомъ посльдовавшаго распоряженія о выпздп его изб Москвы и признавая такое восхваленіе крайне неумпстнымғ, $я^{20}$ приняль надлежащія мпры къ задержанію номера, - о чемг съ приложеніемь номера импю честь ${ }^{21}$ представить на благоусмотргніе Вашего Превосходительства.

Предспдатель А. Петровъ

Секретарь Н. Пантелеев<ъ><л. 285 об.>

Источник текста: РГИА. Ф. 776.5.1871.95. Ч. 1. Л. 285-285 об.

Документ выполнен рукой писца; подписи - автографы А. Г. Петрова и Н. И. Пантелеева.

Черновая копия документа хранится: РГИА. Ф. 777.2.1871.74. Л. 175-175 об. 


\section{Комментарии:}

Господину Исправляющему должность Начальника Главнаго Управленія по дюламъ печати. - Обязанности начальника Главного управления по делам печати в 1874-1880 гг. исполнял известный профессор-востоковед, публицист Василий Васильевич Григорьев (1816-1881).

при чемъ редакція (сноска 17). - Карандашные пометки здесь и далее по тексту документа сделаны сотрудником Главного управления по делам печати при составлении (на основе отношения С.-Петербургского цензурного комитета) текста протокола заседания Совета Главного управления по делам печати 10 октября 1878 г. (ср. ниже документ 6).

...ричь Аксакова, напечатанная въ приложеніи къ 23-24 номеру... - Аксаков Иван Сергеевич (1823-1886) - знаменитый публицист-славянофил, редактор газет «День» (1861-1865), «Москва» (1867-1868), «Москвич» (1867-1868), «Русь» (1880-1886). В 1876-1878 гг. изредка печатался в «Гражданине». В приложении к № 23-24 «Гражданина» от 4 июля 1878 г. была помещена речь И. С. Аксакова, произнесенная 22 июня на заседании Московского Славянского благотворительного общества и содержавшая протест против ключевых положений Берлинского международного трактата, готовившегося тогда к подписанию (подписан 1 (13) июля 1878 г.). Берлинский трактат, во многом ревизовавший условия СанСтефанского мирного договора 19 февраля (3 марта) 1878 г. между Россией и Турцией и возвращавший в состав Турции уже освобожденную Россией южную Болгарию, характеризовался И. С. Аксаковым как «позорный мир» и «предательство» русской дипломатии по отношению к Болгарии: «Нътъ такихъ и словъ, чтобъ заклеймить по достоинству это предательство, эту измъну историческому завъту, призванію и долгу Россіи. Согласиться на такое рЂшеніе <...> значит утратить <...> не только сочувствіе, но и уваженіе славянскихъ племенъ» (Гражданинъ. 1878. № 23-24, прилож. С. 3). № 23-24 «Гражданина» от 4 июля 1878 г. и приложение к нему были конфискованы по распоряжению председателя С.-Петербургского цензурного комитета (часть тиража номера на момент ареста уже была распространена).

...nомпщено стихотвореніе Аксакова: «Варварино» «злая мгла облегла вершины Руси»<.> - Варварино - село в Юрьев-Польском уезде Владимирской губернии, имение Е. Ф. Тютчевой, сестры жены И. С. Аксакова; во 2-й половине 1878 г. - местопребывание И. С. Аксакова, высланного из Москвы после обнародования (в т. ч. за границей) его речи против Берлинского трактата. Стихотворение «Варварино» не предназначалось Аксаковым к печати и было поставлено В. Ф. Пуцыковичем в номер без согласования с автором (свое недовольство этим И. С. Аксаков выразил, в частности, в письме к Е. А. Свербеевой от 23 октября 1878 г. - см.: ГА РФ. Ф. 109.4а.489. Л. 3-3 об.). В первоначальном варианте № 23-25 «Гражданина» стихотворение И. С. Аксакова «Варварино» было напечатано на c. 451 (из-за сбоя в нумерации страниц журнального выпуска вместо с. 451 указана с. 251). Стихотворение «Варварино» начинается с посвящения Е. Ф. Тютчевой: 
Какъ будто вихремъ бури злой

Снесло мой домъ и я - изгнанникъ!

Но дружба путь водила мой

И вотъ я въ пристани... Я твой

Отнынъ гость и сердцемъ данникъ.

Финальные строфы стихотворения, частично цитируемые сотрудниками цензурного комитета, таковы:

Куда ты взоръ ни обратишь,

Какая ширь! Какая тишь!

Но всюду въ ней снуетъ, безшумный,

Рабочей Руси трудъ святой...

О чудный миръ земли родной,

Какъ полонъ правды ты разумной!

Великій миръ, родимый миръ!

Ты бодръ и мощенъ какъ стихія...

Твоей лишь правдою Россія

Преодольть возможетъ міръ,

И свергнуть идолы чужіе!..

Но часъ не близокъ. Злая мгла

Вершины Руси облегла... (РГИА. Ф. 777.2.1871.74. Л. 169).

...помпщена статья, подъ заглавіемъ: «Воспоминанія объ И. С. Аксакови».. Статья «Воспоминания об И. С. Аксакове» в первоначальной версии № 23-25 «Гражданина» помещена на с. 451-453; автором статьи был В. Ф. Пуцыкович (см.: РГИА. Ф. 777.2.1871.74. Л. 169-170).

...съ приложеніемъ номера... - № 23-25 «Гражданина» был выдан под расписку сотруднику Главного управления по делам печати А. Косоговскому (см. следующий документ).

5.

\section{Расписка сотрудника канцелярии Главного управления по делам печати МВД}

10 октября 1878 г.

№ 23-25 Гражданина для Главнаго Управленія по дюлами печати получиль одинъ экземихиляръ $>$.

$$
\text { Губернс<кій> Секр<етарь> } A<.>\text { Косоговскій }
$$

10 октября 1878 г. <л. 176>

Источник текста: РГИА. Ф. 777.2.1871.74. Л. 176.

\section{Комментарии:}

№ 23-25 Гражданина получиль одинъ экзем<плярб>. - Данный экземпляр сохранился в архиве Главного управления по делам печати (см.: РГИА. Ф. 776.5.1871.95. Ч. 1. Л. 286). В архиве С.-Петербургского цензурного комитета имеются только первые восемь страниц первоначального варианта № 23-25 (с. 449-456 - см.: РГИА. Ф. 777.2.1871.74. Л. 168-171 об.). 
6.

\section{Протокол заседания Совета Главного управления по делам печати МВД 10 октября 1878 г.}

\author{
СОВБТЪ $^{22}$ \\ ГЛАВНАГО УПРАВЛЕНІЯ \\ по \\ ДЪЛАМЪ ПЕЧАТИ \\ М. В. Д. \\ «10» Октября 1878 г<.> \\ № 53.
}

\section{Совпть Главнаго Управленія по диламъ печати слушаль: ${ }^{23}$}

Представленіе Предспдателя $C<$.> Петербургскаго Цензурнаго Комитета о №№ 23-25 журнала «Гражданинъ».

Въ представленномъ сегодня изб типографіи Траншеля 23-25 нумерг «Гражданина», оть 10 Октября, помпщено <л. 412> распоряженіе Г. Министра Внутреннихъ Диоль о пріостановкп журнала на три мгсяи,а, при чемъ редакція сопровождаеть тексть эта $20^{24}$ распоряженія заявленіемъ, что нумеръ журнала, за который объявлено было изданію третье предостереженіе съ пріостановленіемб онаго на три мпсяияа, не могъ быть разослань вспьв подписчикамб, такъ какъ быль въ свое время арестованъ вмпсть съ приложеніемб (рпчью И. С. Аксакова) и не быль впослпдствіи освобожденб, не смотря на ходатайства редакціи.

За тпмг, въ этомь же нумерп 23-25 помпщено стихотвореніе Аксакова: «Варварино», въ началь котораго авторъ заявляеть, что «вихрь злой бури снесъ его домъ и онъ теперь изгнанникъ». Далюе выражается сладостное чувство успокоенія въ тихомь <л. 412 об.> пристанищп, среди прекрасной деревенской природь, и надежда на окончательное преодольніе Россіей враждебнаго ей міра, но счастливый часъ этого торжества не близокб, потому что "злая мгла обтегла вершины Руси».

Далюе помпщена статья, подъ заглавіемъ «Воспоминанія объ И. С. Аксаковп", въ которой съ крайнимъ сочувствіемъ описывается предьидущая журнальная дюятельность Аксакова и заслуги его по предспдательству въ Славянскомг Обществп.

Импя вг виду, что эта прославляемая дптельность Аксакова была поводомь посльдовавшаго распоряженія о выпьздь его изъ Москвы, и признавая такое восхваленіе крайне неумпстнымб, Предспдатель С<.> Петербургскаго Цензурнаго Комитета приняль надлежащія мпры къ задержанію <л. 413> нумера, и представиль на благоусмотрпніе Главнаго Управленія по дюламъ печати.

Принимая во вниманіе, что вг настоящемг случап къ журналу «Гражданинб» не можеть быть примпнено дпйствіе закона 7 Іюня 1872 г., импющаго силу лишь для повременныхъ изданій, выходящихъ ргже одного раза въ недюлю, а между тюмг статья 69 прилож<енія > къ ст. 4 (примпч.) Уст<ава> Ценз<урнаго >, Т. ХIV Св<ода $>$ Зак<оновъ > по продолж<енію> 1876 г., требуетъ, при арестованіи ну мера, одновременнаго начатія противъ виновныхв судебнаго пресльдованія, каковое пресльдованіе въ виду приведеннаго содержанія нумера, представляется совершенно неудобнымб, Совпть, признавъ распоряженіе Предспдателя $C<.>$ Петербургскаго Цензурнаго Комитета объ арестованіи №o 23-25 журнала <л. 413 об.> «Гражданинб» правильнымб, полагаетъ: представить о вышеизложенномь на благоусмотрпніе Его Высокопревосходительства Господина Министра. 


\begin{tabular}{|c|c|}
\hline \multirow{7}{*}{$\begin{array}{l}\text { Предспдательствующій } \\
\text { Члены Совпта: }\end{array}$} & Н. Варадиновъ. \\
\hline & Кн. П. Вяземскій \\
\hline & Ө. Веселаго. \\
\hline & B<.> Лазаревск<iй> \\
\hline & А. Петровъ. \\
\hline & Платонъ Вака̀ръ \\
\hline & $\Theta<.>$ Еленевъ. \\
\hline Правитель Дюль & 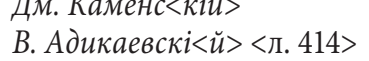 \\
\hline
\end{tabular}

Источник текста: РГИА. Ф. 776.2.18. Л. 412-414.

Текст протокола (кроме подписей должностных лиц) выполнен рукой писца.

\section{Комментарии:}

...заявленіемъ, что нумеръ журнала не быль впослюдствіи освобожденб, не смотря на ходатайства редакціи. - Указанное заявление было помещено под заголовком «От редакции» на первой странице журнального номера (см.: РГИА. Ф. 777.2.1871.74. Л. 168).

...закона 7 Іюня 1872 г. ... - Закон 7 июня 1872 г. - Высочайше утвержденное мнение Государственного совета «О дополнении и изменении некоторых из действующих узаконений о печати». Документ предусматривал возможность конфискации тиражей книг и периодических изданий, выходящих реже одного раза в неделю, без решения суда. Юридическим основанием для конфискации являлось постановление Комитета министров, сделанное по представлению министра внутренних дел (см.: Полное собраніе законовъ Россійской Имперіи. Собр. 2. T. XLVII. Отд. І. СПб., 1875. С. 815-817).

Предспдательствующій Н. Варадиновъ. - Варадинов Николай Васильевич (1817-1886) - юрист, доктор права и доктор философии, составитель восьмитомной «Истории Министерства внутренних дел» (СПб., 1858-1863). Член Совета Главного управления по делам печати в 1865-1883 гг.

Кн. П. Вяземскій - Вяземский Павел Петрович, князь (1820-1888) - историк русской литературы, археограф, исследователь «Слова о полку Игореве»; сын поэта П. А. Вяземского. В 1873-1881 гг. - председатель С.-Петербургского комитета иностранной цензуры, в 1881-1883 гг. - начальник Главного управления по делам печати.

Ө. Веселаго. - Веселаго Феодосий Федорович (1817-1895) - генерал, историк русского флота. С 1860 г. - сотрудник С.-Петербургского цензурного комитета, в 1866-1881 гг. - член Совета Главного управления по делам печати.

$B<.>$ Лазаревск<iй> - Лазаревский Василий Матвеевич (1817-1890) - беллетрист, переводчик трагедий В. Шекспира. Член Совета Главного управления по делам печати в 1866-1890 гг.

А. Петровъ. - Председатель С.-Петербургского цензурного комитета А. Г. Петров (см. комментарий к документу 1). 
Платонъ Вака̀ръ - Вакар Платон Алексеевич (1823-1899) - государственный деятель. С 1867 г. - сотрудник Комитета иностранной цензуры, в 1871-1899 гг. — член Совета Главного управления по делам печати.

$\Theta<.>$ Еленевъ. - Еленев Федор Павлович (1827-1902) - педагог, консервативный публицист. Работал в цензурном ведомстве с 1862 г.; в 1868-1896 гг. - член Совета Главного управления по делам печати.

Дм. Каменс<кій> - Каменский Дмитрий Иванович (1818-1880) - переводчик, журналист, член Совета Главного управления по делам печати в 1869-1880 гг. Доклад Д. И. Каменского на Совете Главного управления 12 марта 1874 г. стал причиной вынесения «Гражданину» первого цензурного предостережения за статью «Два слова по поводу мнения князя Бисмарка о русских немцах» (1874. № 10) (см.: [Летопись, II: 463-464] [Отливанчик, 2005: 168-169]).

Правитель Дюль В. Адикаевскі<ц̆> - Адикаевский Василий Семенович (18351907) - сотрудник Главного управления по делам печати в 1865-1906 гг. С 1877 г. — правитель дел канцелярии ведомства, в 1881-1898 гг. - член Совета Главного управления, в 1898-1906 гг. - фактический глава высшей цензурной инстанции.

7.

\section{Служебная записка временно исправляющего должность начальника Главного управления по делам печати министру внутренних дел}

\section{0 октября 1878 г.}

Вашему Высокопревосходительству долгомь поставляю доложить, что, по

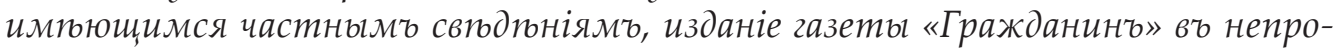
должительномь времени будеть подвергнуто аукиіонной продажп за долги издателя. Поэтому не признано-ли будеть Вашимь Высокопревосходительствомь достаточныль исходатайствовать Высочайшее соизволеніе на уничтоженіе только этого одного нумера, каковое Высочайшее соизволеніе могло бы быть не публикуемо ко всеобщему свпдпнію.

10 октября $18782 .{ }^{25}<$ <. 287>

\section{Н. Варадиновь}

Источник текста: РГИА. Ф. 776.5.1871.95. Ч. 1. Л. 287.

\section{Комментарии:}

...изданіе газеть «Гражданинъ» будеть подвергнуто аукиіонной продажп за долги издателя. - 12 мая 1878 г. в Главное управление по делам печати поступило требование судебного пристава С.-Петербургского окружного суда А. Матусевича о взыскании с издателя «Гражданина» В. Ф. Пуцыковича в пользу купца Д. И. Калугина 800 рублей долга с процентами и неустойкой; взыскание было обращено судом на издательский залог В. Ф. Пуцыковича по «Гражданину» (см.: РГИА. Ф. 776.5.1871.95. Ч. 1. Л. 230). 8 июля 1878 г. последовал повторный запрос судебного пристава А. Матусевича в цензурное ведомство (см.: РГИА. Ф. 776.5.1871.95. Ч. 1. Л. 254-254 об.), а 18 сентября Главным управлением было получено требование судебного пристава при С.-Петербургском столичном мировом съезде 
Сердюкова (инициалы неизв.) о взыскании с В. Ф. Пуцыковича «въ пользу казны гербоваго штрафба 35 рублей» (РГИА. Ф. 776.5.1871.95. Ч. 1. Л. 279-279 об.). 10 октября 1878 г. судебный пристав А. Матусевич сообщал в Главное управление: «...вб настоящее время Г. Калугинъ взысканіе означенной суммы обратиль на издательское право Г. Пуиыковича на журналь “Гражданинъ", которое вслпдствіи (так! А. О.) этого и должно подлежать описи и продажг съ публичнаго торга» (РГИА. Ф. 776.5.1871.95. Ч. 1. Л. 288). Несколькими днями позже о денежных претензиях к В. Ф. Пуцыковичу со стороны владельца типографии А. И. Траншеля и частного кредитора В. Г. Исаева сообщили в цензурное ведомство судебные приставы В. Семенский и Н. Вехняковский (см.: РГИА. Ф. 776.5.1871.95. Ч. 1. Л. 289-290). Издательское право Пуцыковича на «Гражданин» было продано с публичного торга 8 декабря 1878 г. (см.: РГИА. Ф. 777.2.1871.74. Л. 193). История судебных тяжб Пуцыковича с кредиторами частично изложена И. А. Прониной в статье «Последний год “Гражданина”: К истории отношений правительственной цензуры и консервативной печати» (см.: [Пронина: 23-25]).

...только этого одного нумера... - Имеется в ввиду № 23-25 1878 г.

...и заготовить всепод<даннпйшій> докладъ... (сноска 25). - «Всеподданнейший доклад» - доклад министра или др. высокопоставленного должностного лица монарху.

8.

Деловое письмо С.-Петербургского градоначальника председателю С.-Петербургского цензурного комитета

10 октября 1878 г.

С.-ПЕТЕРБУРГСКАГО 26 ГРАДОНАЧАЛЬНИКА

Канцелярія

по дъламъ печати

10 Октября 1878 года № 1438
Господину Предспдателю С<.> Петербургскаго Цензурнаго Комитета

Вслтьдтвіе отношенія оть 10 сего Октября за № 1283, импю честь препроводить при семь къ Вашему Превосходительству протоколь объ арестованіи экземпляровъ № $23 / 25$ газеты «Гражданинъ».

Свиты Его Величества,

Генераль-Маіорь Зуровъ

Старшій Инспекторь Н. Никитинб. <л. 177>

Источник текста: РГИА. Ф. 777.2.1871.74. Л. 177.

Документ выполнен рукой писца; подписи - автографы А. Э. Зурова и Н. В. Никитина. 
9.

Протокол задержания тиража № 23-25 журнала «Гражданин» 1878 г. $<10$ октября 1878 г.>

\section{Протоколь.}

1878 года Октября 10 дня я, Инспекторь книжной торговли, типографій и m. п. заведеній въ С. Петербургп 3. участка Коллежскій Совптникъ Грешнеръ, всльдствіе отношенія Г. Предспдателя С. Петербургскаго Цензурнаго Комитета, послюдовавшаго на имя Г. Старшаго Инспектора оть 10 сего Октлбря за № 1284, прибыль въ типографію Саксонскаго Подданнаго Андрел Траншеля, находящуюся Московской части 1. участка по Стремянной улицью въ домп подъ №. 12, и арестоваль до выпуска въ свпьть № 23-25 журнала «Гражданинъ», отпечатаннаго въ количествп 4 800. экземпляровъ, изь числа которьхь ока-

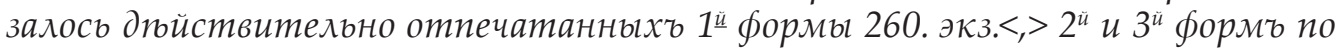

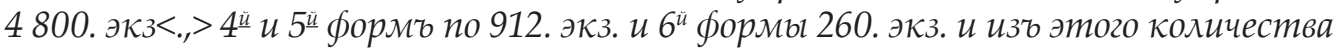
$10^{2<0>}$ сего Октября отослано къ Цензору $\Gamma<$.> Смирнову 1. экз.<,> въ 3е Omдиленіе Собственной Его Величества Канцеляріи 1. экз. и въ С. Петербургскій Цензурный Комитеть подь квитанцію за № 6346 восемь экз. Всп остальные экземпляры, заключаюшіеся въ трехь пачкахъ, опечатань мною казенною печатью и сдань на храненіе, впредь до особаго распоряженія, фактору означенной типографіи Шлиссельбургскому Мющцанину Сергпю добродюеву подь расписку на семь протоколю. Означенныл три пачки приняль на храненіе Сергпй добродпе<въ> 27

Инспекторь 3. участка А<.> Грешнерь <л. 178>

Источник текста: РГИА. Ф. 777.2.1871.74. Л. 178.

Текст протокола выполнен рукой А. Ф. Грешнера; имеется вставка рукой С. Е. Добродеева.

\section{Комментарии:}

...Инспекторв книжной торговли, типограбій и т. п. заведеній въ С. Петербургп 3. участка Коллежскій Совптникъ Грешнеръ... - Грешнер Александр Федорович (? - не ранее 1892) - младший инспектор типографий и книжной торговли в С.-Петербурге в 1877-1881 гг.

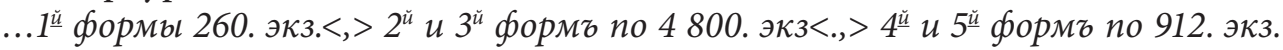
и $6^{\check{u}}$ бормы 260. экз. ... - 1-я форма - первый полулист (8 страниц, половина типографского листа) журнального номера (с. 449-456 в № 23-25 «Гражданина»); 2-я форма - второй полулист (с. 457-464); 3-я форма - третий полулист (с. 465472); 4-я форма - четвертый полулист (с. 473-480); 5-я форма - пятый полулист (c. 481-488); 6-я форма - шестой полулист (с. 489-496).

...къ Цензору $\Gamma<.>$ Смирнову... - Смирнов Андрей Иванович (1813-1883) историк, педагог, цензор С.-Петербургского цензурного комитета в 1865-1881 гг.

...Шлиссельбургскому Мющцанину Сергюю Добродюеву... - Добродеев Сергей Емельянович (1846-1910) - управляющий типографией А. И. Траншеля, впоследствии издатель (1885-1897) и редактор (1887-1896) еженедельного иллюстрированного журнала «Живописное Обозрение». 
10.

\section{Прошение В. Ф. Пуцыковича на имя министра внутренних дел}

11 октября 1878 г.

\author{
РЕДАКЦІЯ ${ }^{28}$ \\ ЖУРНАЛА \\ «ГРАЖДАНИНЪ»
}

С.-Петербургъ,

Надеждинская, д. № 24.

Редакторъ-Издатель

Викторъ Өеофиловичъ

Пуцыковичъ.

Членъ «С.-петербургскаго славянскаго благ. общества», «Юридическаго общества при Император-

скомъ московскомъ

университетъ», «Императорскаго

общества содъйствія русскому

торговому мореходству», «Императорскаго русскаго географическаго общества»; пожизненный членъ «Общества пособія литераторамъ и ученымъ» и почетный пожизненный членъ «Русскаго академическаго общества Буковина» при вЂнскомъ университетъ.
Bаше Высокопревосходительство Милостивый Государь

Александрг Егоровичъ!

10 Октября по распоряженію г. Предспдателя Цензурнаго Комитета арестованъ 23-25 № «Гражданина» по случаю помпщеннаго въ немг стихотворенія 2. Аксакова и моей о немг статьи.

Импя въ виду, что какъ стихотвореніе, такъ и статья по моему убюжденію отличаются благонампренностью и не нарушають никакихь правительственныхъ распоряженій, я имюю честь покорнпйше просить Васъ сдплать распоряженіе объ освобожденіи сего №.

Если же это сдплать Ваше <л. 179> Высокопревосходительство не найдете удобнымъ, то импю честь убгдительнпйше просить Вась приказать считать арестованнымъ и избятымг изг обращенія только первый полулисть заключающій вспь упомянутыя статьи, а остальные 5 полулистовь разртьшить мнпь выпустить теперь же сб предоставленіемг мнг вг арестованномб первомг полулисть исключить всп статьи, подавшія поводъ кr аресту.

Оставленіе же всего № подт арестомъ впредь до разрпшенія дюла о первомг полулисть нанесеть мнг крайній вредъ по журналу и я вгороятно вынужденъ буду его прекратить, - что тишить правительство органа, который, смпю думать, занимаеть не послпднее мпсто по <л. 180> своей искренней благонампренности.

Прошу принять Ваше Высокопревосходительство увтреніе въ совершенномг къ Вамъ почтеніи Вашего всепокорнаго слуги В. Пуцыковича

11 окт<ября > 1878 г. <л. 180 об.>

Источник текста: РГИА. Ф. 777.2.1871.74. Л. 179-180 об.

\section{Комментарии:}

...Милостивый Государь Александръ Егоровичъ! - Тимашев Александр Егорович (1818-1893) - военный и государственный деятель, управляющий III Отделением Собственной Его Императорского Величества канцелярии в 1856-1861 гг., министр внутренних дел в 1868-1878 гг. Анонимное сатирическое стихотворение «Послания», направленное против А. Е. Тимашева как управляющего III Отделением (заведением «у Цепного моста») и опубликованное в 1861 г. в «Полярной Звезде», частично цитируется Ф. М. Достоевским в «Братьях Карамазовых» (см.: Д30, 14, 501; $15,585)$. 
11.

\section{Отношение С.-Петербургского цензурного комитета на имя старшего инспектора типографий и книжной торговли в С.-Петербурге (черновик)}

13 октября 1878 г.

«13» Октября 1878 2. № $1300^{29}$

Господину Старшему Инспектору типографій и т. п. заведеній въ СПбего

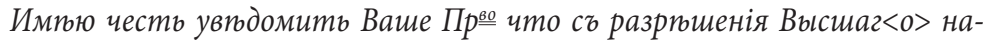
чальства признано возможнымб снять аресть съ задержанныхъ ровб номера 23-25 газеты "Гражданинб» за исключеніемь только перваго листа<,> въ которомь ${ }^{31}$ должны быть перепечатаны странииы - 249<,> 251, 252 и 253 «Оть редакиіи», стихотвореніе «Варварино»-Аксакова и статья Пуиыковича «Воспоминанія объ И. С. Аксаковп».

Этоть листь долженг остаться арестованнымъ, а остальные листь

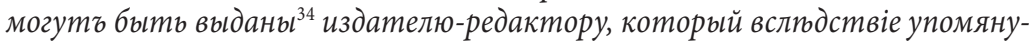
таго ${ }^{35}$ распоряженія Высшаго начальства ${ }^{36}$ обязанъ первый тисть, въ зампнг арестованнаго, печатать не иначе какъ по предварительномь представленіи онаго на просмотрг въ К<омите >ть.

Объ означенномг импю честь сообщить Вашему Превосходительству для принятія соотвптственныхъ со стороны Вашей распоряженій, при

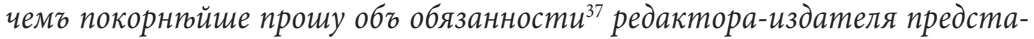
вить ${ }^{38}$ новый первый листь номера на просмотрь К<омите >mа поставить въ извтостность Типографію Траншеля, гдь газета «Гражданинб» печатается.

Предспдатель

Секретарь <л. 181>

Источник текста: РГИА. Ф. 777.2.1871.74. Л. 181.

Черновик выполнен рукой секретаря С.-Петербургского цензурного комитета Н. И. Пантелеева.

\section{Комментарии:}

...cъ разрпшенія Высшаг<о начальства... - Имеется в виду разрешительная резолюция А. Е. Тимашева на прошении В. Ф. Пуцыковича от 11 октября 1878 г. (см. предыдущий документ). Прошение Пуцыковича было после рассмотрения направлено А. Е. Тимашевым в С.-Петербургский цензурный комитет и сохранилось в его архиве.

...странииьь - 249<,> 251, 252 и 253... - В № 23-25 «Гражданина» 1878 г. налицо сбой в нумерации страниц. Номера страниц 457-489 журнального выпуска указаны правильно, тогда как вместо страниц 450-456 в первоначальном варианте номера обозначены страницы 250-256, вместо страниц 490-496 - страницы 290-296. На первой странице № 23-25 (с. 449) номер не проставлен. При замене первого полулиста № 23-25 новой версией ошибка в нумерации страниц 450-456 была исправлена. 
12.

Деловое письмо старшего инспектора типографий и книжной торговли в С.-Петербурге председателю С.-Петербургского цензурного комитета 14 октября 1878 г.

М. В. Д. ${ }^{39}$

\section{СТАРШИЙ ИНСПЕКТОРЪ}

типографій и т. п. заведеній

а также книжной торговли.

въ С.-Петербургъ.

Господину Предспдателю $C<.>$ Петербургскаго Цензурнаго Kомитета

Вслпдствіе отношенія оть 13о сего Октября за № 1300, импю честь препроводить къ Вашему Превосходительству

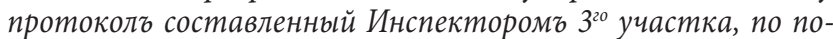
воду снятія ареста съ номера $23 / 2$ газеты «Гражданинъ» и об опечатаніи перваго листа названнаго номера ${ }^{40}$.

14 Октября 1878 г.

№ 1465

Старшій Инспекторв Н. Никитинъ. <л. 182>

Источник текста: РГИА. Ф. 777.2.1871.74. Л. 182.

Документ выполнен рукой писца; подпись - автограф Н. В. Никитина.

13.

Протокол снятия ареста с тиража № 23-25 журнала «Гражданин» 1878 г. $<13$ октября 1878 г.>

Протоколь.

1878 года Октября 13 дня я, Инспекторь книжной торговли, типографій и т. п. заведеній въ С. Петербургп 3оㅡㄴлка, Коллежскій Совютникъ Грешнерь, вслюдствіе отношенія Г. Предспдателя С. Петербургскаго Цензурнаго Комитета оть 13 сего Октября за № 1300, прибьль въ типографію Траншеля, находящуюся Московской части 1. участка по Стремянной улици въ домп подь № 12 и сняль аресть съ отпечатаннаго № 23-25 журнала «Гражданинъ», за исключеніемь перваго полулиста въ количествп 260. экз.<,> въ которомь заключаются ${ }^{41}$ страниць 249, 251, 252 и 253, на коихь помпщень признанныя неудобными: «Заявленія оть редакціи», стихотвореніе «Варварино» Аксакова и статья Пуцьковича "Воспоминаніе ${ }^{42}$ объ И. С. Аксаковп». Означенные 260. экз<.>, заключающіеся въ двухъ пачкахь и опечатанные казенною печатью, сдань мною на храненіе фактору упомянутой типографіи Г. Добродпеву подь расписку на семь протоколь, а Редакторь-издатель газеть «Гражданинъ» облзань подпискою на семь же первьй листь, въ зампнь арестованнаго, печатать не иначе, какь по предварительномь представленіи онаго на просмотрь въ Цензурный Комитеть. Редакторь-Издатель журнала «Гражданинъ» Викторь Өеофиловь Пуцьковичь ${ }^{43}<.>$ Упомянутыл двп пачки опечатанныл казенною печатью на храненіе приняль<,> и объ обязанности г. Пуцььковича о представленіи въ цзензурньй комитеть взампнъ арестованнаго мннь объявлено<.> Управляющій muпографіей $C<.>$ Добродпевъ ${ }^{44}<$.> 
Инспекторь 3 участка $A<.>$ Грешнерь <л. 183>

Источник текста: РГИА. Ф. 777.2.1871.74. Л. 183.

Текст протокола выполнен рукой А. Ф. Грешнера; имеются вставки рукой В. Ф. Пуцыковича и рукой С. Е. Добродеева.

\section{Комментарии:}

...страницы 249, 251, 252 и 253... - В окончательном варианте № 23-25 данные страницы имеют номера 449, 451, 452 и 453. О сбое в нумерации страниц № 23-25 «Гражданина» см. комментарий к документу 11.

«Заявленія отъ редакціи» - Имеется в виду заметка «От редакции» на первой странице № 23-25 «Гражданина».

\section{4.}

Уведомление С.-Петербургского цензурного комитета в типографию

\section{А. И. Траншеля (черновик)}

14 октября 1878 г.

М. В. Д.

С.-ПЕТЕРБУРГСКІЙ ЦЕНЗУРНЫЙ КОМИТЕТЬ.

«14» Октября 1878 г.

№ 1319 .

Канцелярія СПб. Ц<ензурнаго> К<омите>та, по приказанію Г. Предспдателя, извпщаеть Типографію Траншеля, что къ выпуску въ свпть исправленнаго ${ }^{45}$ № 23/25 газеты «Гражданинб» вб такомб видп, въ какомб онб представленб вб К<омите>ть сего 14 октября, препятствій со стороны Цензурнаго К<омите>та не встртиается.

Секретарь <л. 188>

Источник текста: РГИА. Ф. 777.2.1871.74. Л. 188.

Черновик выполнен рукой секретаря С.-Петербургского цензурного комитета Н. И. Пантелеева.

15.

Уведомление С.-Петербургского цензурного комитета на имя

С.-Петербургского почт-директора (копия)

16 октября 1878 г.

«16» октября

1878 2<.>

№ 1321
Г. СПб. Почтъ Директору.

Вб дополненіе къ отношенію моему отъ 10 октября за № 1285 импю честь увюдомить Ваше Прев, что причинь, препятствовавшія выходу въ свпть № 23-25 газеть «Гражданинъ», отъ 10⿱ тек<ущаго> октября, нынт устранены и номерг этоть можеть быть разосланб подписчикамъ.

Предспдатель (подписаль) А. Петровъ

Секретарь (скрппиль) Н. Пантелеевъ <л. 189> 
Источник текста: РГИА. Ф. 777.2.1871.74. Л. 189.

Копия выполнена рукой секретаря С.-Петербургского цензурного комитета Н. И. Пантелеева.

16.

Уведомление временно исправляющего должность С.-Петербургского почтдиректора на имя председателя С.-Петербургского цензурного комитета 16 октября 1878 г.

САНКТПЕТЕРБУРГСКІЙ ${ }^{46}$ ПОЧТЬ-ДИРЕКТОРЬ

$\mathrm{C}<$.>-Петербургъ

«16» Октября 1878 г.

№ 43788 .
Господину Предспдателю С<.> Петербургскаго Цензурнаго Комитета.

На отношеніе оть 10² сего Октября за № 1285, импю честь увпдомить Ваше Превосходительство, что № $23 / 25$ газеть «Гражданинъ», для разсылки городскимъ и иногороднымб подписчикамъ въ Почтамть доставляемо небыло.

За Почть-Директора В<.> Ломов<ъ $><$ л. 190>

Источник текста: РГИА. Ф. 777.2.1871.74. Л. 190.

Документ выполнен рукой писца; подпись - автограф В. Ломова.

Автор выражает признательность В. С. Зинковой за помощь в подготовке данной публикации.

\section{ПРИМЕЧАНИЯ}

* Исследование выполнено при финансовой поддержке РФФИ, проект «Редакционный архив газеты-журнала “Гражданин” (1872-1879 гг.)» № 17-04-00619-ОГН.

1 Отметим, что должности секретаря в штате Главного управления по делам печати МВД не существовало.

2 Экземпляр одной из них имеется и в архиве Главного управления по делам печати в деле «Гражданина» (см.: РГИА. Ф. 776.5.1871.95. Ч. 1. Л. 285-285 об.).

3 Изъ записной книжки «Русскаго Архива» // Русскій Архивъ. 1903. № 12. С. 670.

4 Господину вписано рукой секретаря С.-Петербургского цензурного комитета Н. И. Пантелеева.

5 Окончания в словах $C<.>$ Петербургскому и Градоначальнику вписаны секретарем С.-Петербургского цензурного комитета Н. И. Пантелеевым.

6 23/25 вписано рукой Н. И. Пантелеева.

7 «Гражданинъ» вписано рукой Н. И. Пантелеева.

$810^{20}$ октября, вписано рукой Н. И. Пантелеева.

9 Траншеля (Стремянная, 12). вписано рукой Н. И. Пантелеева.

10 23’25 вписано.

11 Вместо: «Гражданинъ» отъ 10 октября - было: «Русское обозрпніе »

12 Н. Пантелеев<ъ> - автограф Н. И. Пантелеева.

13 23/25 вписано.

14 Вместо: <«>Гражданинъ», отъ 10 сего октября - было: «русское Обозрпніе» 
15 Далее было (с абзаца): Газета «Русское Обозрпніе» издается Коллежскимъ Совптникомъ Григоріемъ Градовскимъ подъ его же редакиіею

16 На документе в левом верхнем углу помета канцелярии Главного управления по делам печати: № 4359; в правом верхнем углу штамп (дата поступления документа в ведомство): 11 ОКТ 1878.

17 Рядом с фразой - запись карандашом рукой сотрудника Главного управления по делам печати: при чемъ редакція

18 Карандашом (очевидно, рукой сотрудника Главного управления по делам печати) двоеточие исправлено на запятую.

19 Далее вставка карандашом рукой сотрудника Главного управления по делам печати: его

20 Карандашом рукой сотрудника Главного управления по делам печати я зачеркнуто, над строкой сделана запись: Председатель СПб. Ц<ензурнаго> Ком<итета>

21 Над словами: о чемъ съ приложеніемъ номера импю честь - запись карандашом рукой сотрудника Главного управления по делам печати: $и$ представиль на благоусмотрпніе Гл<авнаго $>$ Урр<авленія $>$ по д<пламъ печати $>$

22 В правом верхнем углу страницы рукой министра внутренних дел А. Е. Тимашева написано: Согласенъ<.> 10 окт. 1878

Совпть Главнаго Управленія по дюламъ печати слушаль: - печатный текст.

Так в подлиннике.

25 На записке резолюция рукой министра внутренних дел А. Е. Тимашева: № задержать и заготовить всепод<даннпйщій> докладъ; но при этомь импть въ виду что и въ сльдующихъ №№ могутъ бъьть помпщень такія же статьи.

Означенныя три пачки приняль на храненіе Сергпй Добродюе<въ > - автограф С. Е. Добродеева.

28 Вверху на полях резолюция рукой министра внутренних дел А. Е. Тимашева: Согласенб, но съ тпмъ чтобы исправленный № быль представленъ на предварительный просмотръ. 12 ок<тября>

Ниже отметка должностного лица: Чит<алъ>

Вместо: съ разртьшенія Высшаг<о > начальства признано возможнымъ снять аресть съ задержанныхъ - было: [арестованные] съ задержанныхъ

31 Вместо: которомъ - было: коемъ

32 Вместо: за исключеніемъ только перваго листа<,> въ которомъ должны быть перепечатаны страницы - 249<,> 251, 252 и 253 - было: признано возможнымъ снять аресть, но съ тпмг чтобы арестованъ быль лишь первый листь номера, а именно странии[ъ] $/$ ы / 249-253 (начиная съ заглавн[аго]/ой/)

33 признанныя неудобными вписано.

Вместо: выданы - было: отданы упомянутаго вписано.

всльдствіе упомянутаго распоряженія Высшаго начальства вписано.

Вместо: обязанности - было: обязательствн

Далее было начато: пер

Вверху на полях канцелярская помета: № 1252. 14 Октября 1878 г<.>

В подлиннике описка: намера

заключаются вписано.

Так в подлиннике (должно быть: Воспоминанія). 
43 Редакторв-Издатель журнала «Гражданинъ» Викторъ Өеофиловъ Пуцыковичъ - автограф В. Ф. Пуцыковича.

44 Упомянутья двю пачки Управляющій типографбей $C<.>$ Добродюевъ - автограф С. Е. Добродеева.

45 исправленнаго вписано.

46 Вверху на полях канцелярская помета: № 126918 Октября 1878 г<.>

\section{СПИСОК ЛИТЕРАТУРЫ}

1. Летопись жизни и творчества Ф. М. Достоевского: в 3 т. - СПб.: Академический проект, 1993-1995.

2. Отливанчик А. В. К цензурной истории еженедельника «Гражданин» // Достоевский и современность. Материалы ХIX Международных Старорусских чтений 2004 года. Великий Новгород, 2005. - С. 165-170.

3. Отливанчик А. В. Достоевский и В. Ф. Пуцыкович: к истории взаимоотношений // Достоевский и современность. Материалы XXIV Международных Старорусских чтений 2009 года. - Великий Новгород, 2010. - С. 200-209.

4. Пронина И. А. Последний год «Гражданина»: К истории отношений правительственной цензуры и консервативной печати // Вестник Волгоградского государственного университета: Сер. 4. - 2006. - № 11. - С. 23-30.

Дата поступления в редакиию: 01.09.2018

\section{Alexander V. Otlivanchik}

(Minsk, the Republic of Belarus)

AlexOt@yandex.ru

\section{When Was the Feuilleton by F. M. Dostoevsky "Triton" Published? \\ On the Censorship History of the Weekly Journal "Grazhdanin" (“The Citizen") in 1878}

Acknowledgments. The reported study was funded by RFBR according to the research project № 17-04-00619-OGN.

Abstract: The article clarifies the censorship history of the issues № 23-25 of the weekly "Grazhdanin" ("The Citizen") in 1878, containing F. Dostoevsky's feuilleton “Triton" ("Based on the country walks of Kuzma Prutkov and his friend"), the last known published work of the writer in this journal when it used to be published in St. Petersburg. Based on a number of documents found in the archives of St. Petersburg Censorship Committee and the General Directorate of the Press of the Ministry of Internal Affairs, it was established that the entire circulation of issues № 23-25 of “Grazhdanin” Journal (“The Citizen”), dated October 10, 1878, was arrested by censorship authorities and designated for destruction; the reason for the punitive measures was the material of the issue, which expressed sympathy to the disgraced publicist and public figure I. S. Aksakov. The editor and publisher of "Grazhdanin" ("The Citizen") V. F. Putsykovich, who filed a petition to the Minister of the Interior A. E. Timashev on October 11, 1878, managed to fight back the arrested issue of the journal by agreeing to amend its content and to reprint some of its pages. The Corrected issue № 23-25 of "Grazhdanin” (“The Citizen”) with the "Triton” 
feuilleton was released no earlier than October 16, 1878. The documents illustrating the history of publication of the issue №. 23-25 of "Grazhdanin" ("The Citizen”) revealed in the archives of censorship authorities have been published for the first time; the publication of documents is accompanied by a real comment.

Keywords: “Grazhdanin” (“The Citizen”), V. F. Putsykovich, I. S. Aksakov, “Triton” feuilleton, St. Petersburg Censorship Committee

\section{REFERENCES}

1. Letopis'zhizni i tvorchestva F. M. Dostoevskogo: $v 3$ tomakh [The Chronicle of Dostoevsky's Life and Works: in 3 Vols]. St. Petersburg, Akademicheskiy proekt Publ., 1993-1995. (In Russ.)

2. Otlivanchik A. V. More on the Censorship History of the Weekly Journal "Grazhdanin" ("The Citizen”). In: Dostoyevskiy i sovremennost'. Materialy XIX Mezhdunarodnykh Starorusskikh chteniy 2004 goda [Dostoevsky and the Modern Age. Proceedings of the 19th International Old Russian Readings 2004]. Veliky Novgorod, 2005, pp. 165-170. (In Russ.)

3. Otlivanchik A. V. Dostoevsky and V. F. Putsykovich: On the History of Interrelationships. In: Dostoyevskiy i sovremennost'. Materialy XXIV Mezhdunarodnykh Starorusskikh chteniy 2009 goda [Dostoevsky and the Moder Age. Materials of the 24th International Old-Russian Readings 2009]. Veliky Novgorod, 2010, pp. 200-209. (In Russ.)

4. Pronina I. A. The Last Year of the weekly "Grazhdanin” (“The Citizen”): On the History of Relations between Government Censorship and the Conservative Press. In: Vestnik Volgogradskogo gosudarstvennogo universiteta: Seriya 4 [Science Journal of Volgograd State University. Ser. 4]. 2006. no. 11, pp. 23-30. (In Russ.)

Received: September 1, 2018 